\title{
ESTADÍSTICAS DE ARTÍCULOS \\ ACEPTADOS Y RECHAZADOS
}

Artículos recibidos: 11

Artículos aceptados: 5 (45,5\%)

Artículos rechazados: $6(54,5 \%)$

Trabajos en otras secciones: 2

Autores extranjeros: 2

Autores nacionales: 5

Trabajos que han necesitado un tercer informe: 1

Trabajos que han necesitado revisión: 3

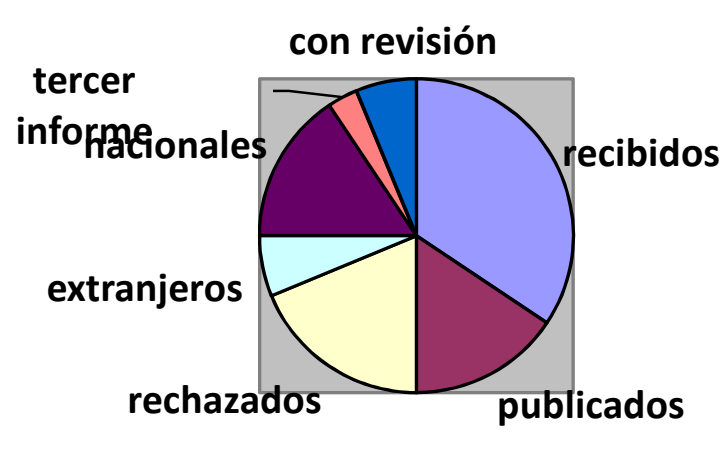

$\square$ recibidos

$\square$ publicados

$\square$ rechazados

$\square$ extranjeros

$\square$ nacionales

$\square$ tercer informe

$\square$ con revisión 